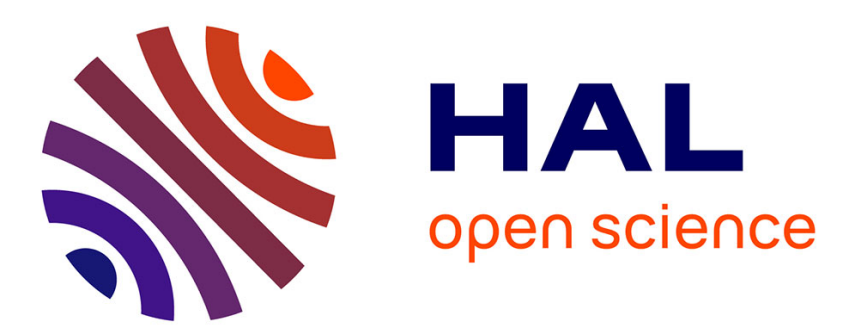

\title{
FABRICATION OF HIGH EFFICIENCY SILICON SOLAR CELLS BY LASER INDUCED DIFFUSION
}

E. Fogarassy, P. Siffert

\section{To cite this version:}

E. Fogarassy, P. Siffert. FABRICATION OF HIGH EFFICIENCY SILICON SOLAR CELLS BY LASER INDUCED DIFFUSION. Congress on Laser-Solid Interactions and Transient Thermal Processing of Materials, 1983, Strasbourg, France. pp.C5-363-C5-368, 10.1051/jphyscol:1983553 . jpa00223139

\section{HAL Id: jpa-00223139 https://hal.science/jpa-00223139}

Submitted on 1 Jan 1983

HAL is a multi-disciplinary open access archive for the deposit and dissemination of scientific research documents, whether they are published or not. The documents may come from teaching and research institutions in France or abroad, or from public or private research centers.
L'archive ouverte pluridisciplinaire HAL, est destinée au dépôt et à la diffusion de documents scientifiques de niveau recherche, publiés ou non, émanant des établissements d'enseignement et de recherche français ou étrangers, des laboratoires publics ou privés. 


\title{
FABRICATION OF HIGH EFFICIENCY SILICON SOLAR CELLS BY LASER INDUCED DIFFUSION
}

\author{
E. Fogarassy and P. Siffert \\ Centre de Recherches Nuctéaires, Laboratoire PHASE, \\ 67037 Strasbourg Cedex, Fronce
}

\begin{abstract}
Résumé - La diffusion de films minces ( $v 50$ A) d'antimoine, déposés sur des substrats cristallins de silicium, a été induite au moyen d'un laser YAG à taux élevé de répétition $(5 \mathrm{KHz})$, déTivrant à la longueur d'onde de $0,53 \mathrm{mj}-$ cron, des impulsions dont la durée est de $100 \mathrm{~ns}$, à une énergie de $2 \mathrm{~J} / \mathrm{cm}^{2}$. Le faisceau de 100 microns de diamētre est balayé afin de traiter de grandes surfaces.
\end{abstract}

Les propriētês des jonctions ainsi obtenues, ont èté analysées et leurs caractéristiques photovoltaiques mesurées pour des conditions AM1 d'illumination. Les résultats montrent que l'utilisation d'un laser pulsé et balayé permet de préparer des cellules solaires de grande surface qui présentent des efficacités de conversion comprises entre 15 et $16 \%$.

\begin{abstract}
The diffusion of thin films ( $\sim 50 \AA$ ) of antimony, deposited on single crystalline silicon, has been induced by irradiating the wafers with a high repetitive $(5 \mathrm{KHz})$ CW pumped $Y A G$ laser emitting at 0.53 micron wavelength pulses of $100 \mathrm{~ns}$ duration at an energy of $2 \mathrm{~J} / \mathrm{cm}^{-2}$. The $100 \mathrm{microns}$ in diameter spots are scanned over large areas with controlled pulse overlapping by a microprocessor set-up.
\end{abstract}

The properties of the laser processed junctions have been analyzed and their photovoltaic characteristics determined under AM1 illumination conditions. The results demonstrate that the use of scanned overlapping laser pulses allows to prepare large area solar cells, which present efficiencies between 15 and $16 \%$.

\section{INTRODUCTION}

Thin film deposition followed by pulsed laser treatment has been demonstrated to be a very interesting technique for junction formation, especially in solar cells fabrication $/ 1,2 /$. Several advantages of laser processing cannot be realized by conventional thermal annealing. The localization of the thermal effects of the laser radiation in a thin surface layer without disturbing the underlying material, the control of the dopant distribution profile, and the complete electrical activation of dopant atoms at concentrations exceeding the thermal equilibrium solubility limit are important factors for preparation of high efficiency silicon solar cells. Furthermore the laser annealing is an easily automatized technique which can be carried in air. These properties are well adapted to the development of a low cost and large scale solar energy production.

This paper presents our best results obtained in preparing high efficiency and large area solar cells by laser induced diffusion of thin films of dopant in crystalline silicon, using scanned overlapping YAG laser pulses. 


\section{EXPERIMENTAL CONDITIONS}

Samples used in this work were $300 \mu \mathrm{m}$ thick <111> oriented slices of silicon cut from a boron doped Czochralski crystal $(1.5-3 \Omega \mathrm{cm}$ resistivity). The samples were chemically polished with a white etch. ( $\left.\mathrm{HF}: 1, \mathrm{HNO}_{3}: 3\right)$. Before deposition of the dopant, they were rinsed in HF to remove the surface oxide.

Thin films of antimony, of about $50 \AA$ thick, as measured by a quartz monitor, were evaporated by Joule effect under vacuum ( $P \simeq 10^{-5}$ torr). The amount of dopant deposited ( $21.5 \times 10^{16} \mathrm{~cm}^{-2}$ ) was measured by Rutherford Backscattering Spectrometry (RBS).

The dopant covered samples were irradiated using a high repetitive ( $5 \mathrm{KHz}) \mathrm{Q}$ - switched - YAG laser $(\lambda=0.53 \mu \mathrm{m})$ which delivers pulses of about $100 \mu \mathrm{m}$ in diameter of $100 \mathrm{~ns}$ duration and an energy density of 1.5 to $2.5 \mathrm{~J} / \mathrm{cm}^{2}$.

The pulse overlapping can be adjusted and the full set up is microprocessor controlled.

The contacts were deposited on mesa structures, with areas ranging between 1 and 7 $\mathrm{cm}^{2}$. The back contact was usually made by evaporation under vacuum of a layer of Au or Ti-Ag. The collection grid of the solar cell was prepared by evaporation of Ag through a mask, with thicknesses comprised between 0.5 and $2 \mu \mathrm{m}$. Finally, an anti-reflective coating of $700 \AA$ of SiO was deposited.

The concentration profiles of total and interstitial dopant were determined by RBS in random and channeling conditions. A $1 \mathrm{MeV}^{4} \mathrm{He}^{+}$ion beam $(\phi \sim 2 \mathrm{~mm})$ was used and the energy of the backscattered particles was measured with a cooled surface barrier detector. This arrangement allowed as equivalent depth resolution of $200 \mathrm{~A}$ for Si.

The sheet resistance of the doped layers was measured by using a four point probe and the carrier concentration profiles were determined by means of the differential sheet resistivity in combination with anodic oxidation and stripping technique.

The junction properties were deduced from dark $C-V$ and $I-V$ measurements and the characteristics of the solar cells were evaluated at $28^{\circ} \mathrm{C}$, in a simulator using an ELH Tamp, which produces a reasonable approximation of the AM1 spectrum when adjusted to the energy level of $100 \pm 2 \mathrm{~mW} / \mathrm{cm}^{2}$, as indicated by a calibrated cell.

\section{DISTRIBUTION PROFILES}

Typical random and channeling RBS spectra of a $50 \AA \mathrm{A}$ Sb deposited film on $\langle 111\rangle \mathrm{Si}$ after laser induced diffusion are shown on Fig. 1. As a result of the laser irradiation $\left(E=2.5 \mathrm{~J} / \mathrm{cm}^{2}\right)$, the dopant is driven into the molten surface region by $1 \mathrm{i}$ quid phase diffusion $\left(D_{L} \simeq 10^{-4} \mathrm{~cm}^{2} / \mathrm{sec}\right) / 3 /$.

After epitaxial regrowth the $S b$ doped layer consists of two regions: A top surface layer containing about $40 \%$ of the initial dopant where the Sb atoms are large $1 y$ non substitutional. An in depth profile which extends on several thousands angstroems and which contains highly substtitutional $\mathrm{Sb}$ with a maximum concentration $c_{S} \sim 9.5 \times 10^{20} \mathrm{~cm}^{-3}$, much higher than the thermal equilibrium solubility limit $\left(C_{S}^{0} \simeq 6 \times 10^{19} \mathrm{~cm}^{-3}\right.$ at $\left.T=1200^{\circ} \mathrm{C}\right)$.

The presence of a surface peak can be mainly attributed to a surface accumulation of antimony by a segregation effect at solid-liquid interface during the regrowth of the molten layer. Due to the high value of the interface velocity $(\mathrm{V} \sim 1.5-2 \mathrm{~m} / \mathrm{s})$ 


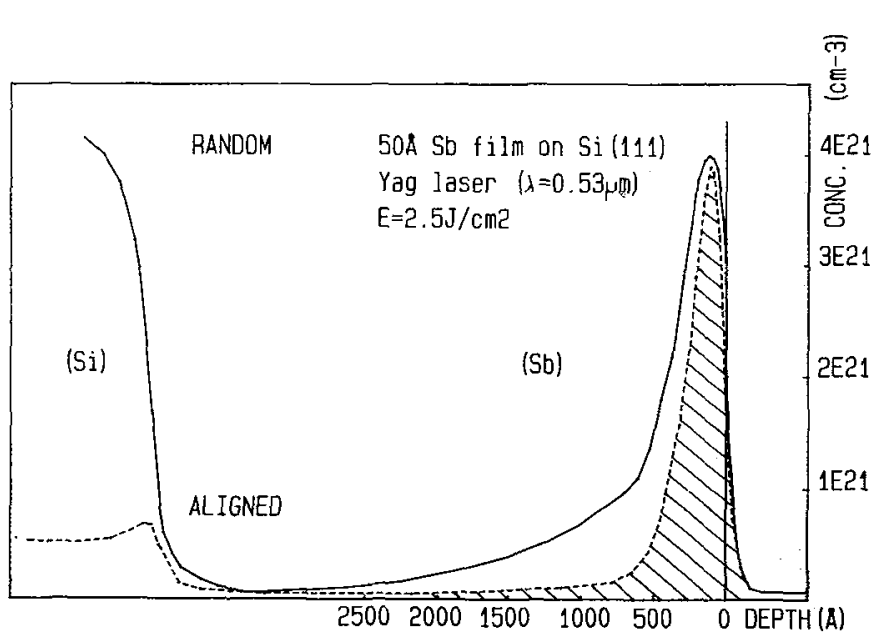

Fig. 1 - RBS spectra, under random and channeling conditions, after YAG laser induced diffusion of $S b$ in silicon. as deduced from heat flow calculations /4/ performed for 100 ns duration single pulse $Y A G$ irradiation, the interfacial segregation coefficient $k$ is much higher than the thermal equilibrium segregation coefficient $(K \approx 0.023$ for $S b)$. As shown in a previous work $/ 6 /$, the linear relation : $c_{s}=c_{s}^{0} \times \frac{K}{K_{0}}$ allows to deduce the value of $k$, which is about 0.3 .

We must notice that the laser annealing process using the overlapping spot method also contributes to enhance the cumulative effect of $K<1$, when compared to the large area single pulse laser irradiation./6/.

As shown on the carrier distribution profile reported on Fig. 3, the surface presents metallic properties and the value of the maximum carrier concentration $\left(\sim 1 \times 10^{21}\right.$ $\mathrm{cm}^{-3}$ ), demonstrates the fully electrical activity of the substitutional dopant. It results a very low sheet resistance of the doped layers by this method which are in the range of $10-15 \Omega /$

\section{JUNCTION PROPERTIES}

The dark forward and reserve current voltage characteristics of a laser processed junction and of a conventionally thermal diffused diode, are reported on Fig. 3 .

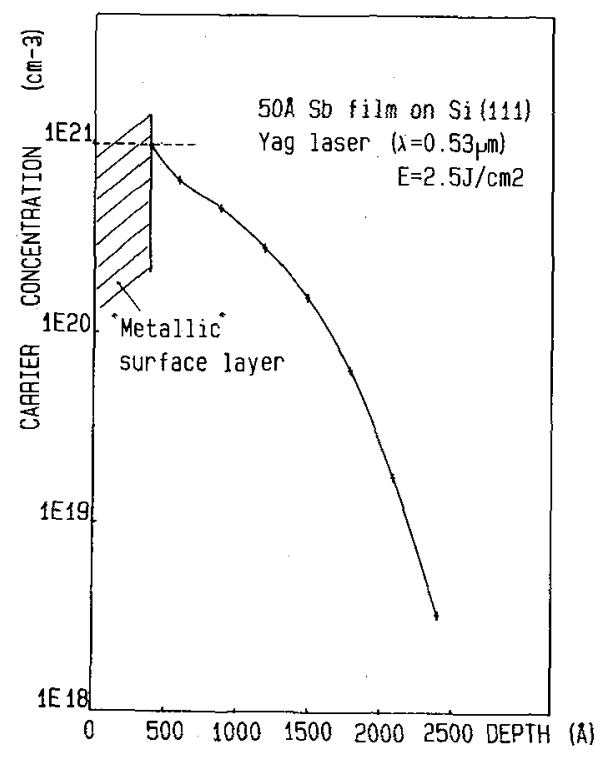

Fig. 2 - Carrier distribution profile as a function of depth.

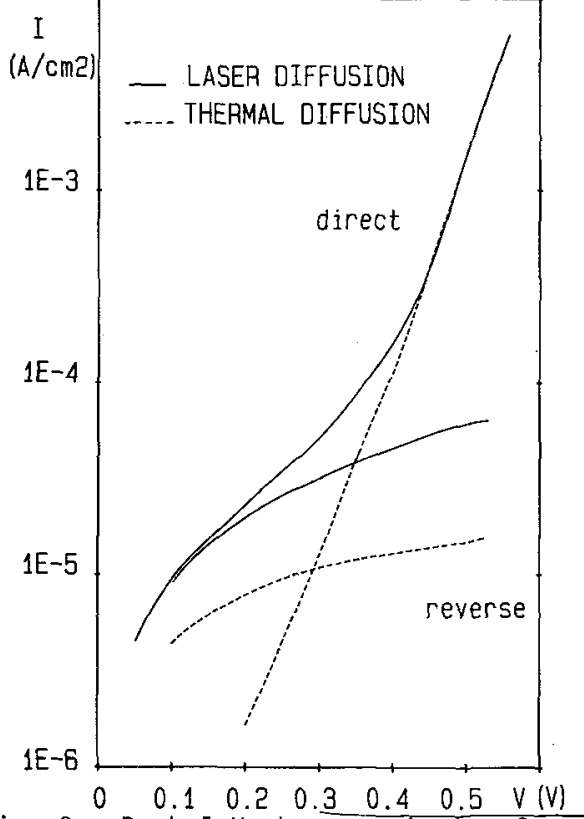

Fig. 3 - Dark I-V characteristics for Taser processed junction $(\rightarrow,-\infty)$ and 
It appears that they follow a double exponential relationship of the form :

$$
J=J_{o r} \exp \frac{q V}{n_{r} K T}+J_{o d} \cdot \exp \frac{q V}{n_{r} K T}
$$

where $n_{r}$ and $n_{d}$ are the recombination and diffusion quality factors respectiveiy, and $J_{o r}$ and $J_{o d}$ the recombination and diffusion saturation currents. These parameters have been deduced from the experimental curves and give, for the thermal diffused junction :

$$
n_{r}=n_{d} \simeq 1.7 \text { and } J_{o r}=J_{o d} \simeq 1 \times 10^{-8} \mathrm{~A} / \mathrm{cm}^{2}
$$

On the contrary, the laser processed junction exhibits high recombination factor $n_{r} \simeq 4.2$ and a recombination current density

$$
J_{\text {or }} \simeq 4 \times 10^{-4} \mathrm{~A} / \mathrm{cm}^{2}
$$

implying the existence of a larger space-charge region and surface concentration of defects that act as generation-recombination centers. Furthermore, the laser processed junction presents a reserve biased leakage current (measured at 1 volt), which is one order of magnitude higher than for the thermal diffused diode. This behaviour can be mainly related to the high surface recombination effects which have several origins: high surface conductivity; heavy doping effects, dangling bonds, surface roughness induced by the laser treatment as confirmed by Talystep and microscopic observations. However, we must also take into account on the influence of donor defects, introduced by the laser irradiation in the treated layer, as demonstrated by Kimerling $/ 7 /$. This is confirmed by $C-V$ measurements, as reported on Fig. 4, where we observe two regions : at high reserve voltage we have a linear dependence on $1 / C^{2}$ as a function of $\left(V+V_{b}\right)$, whereas at low reserve voltage, for $V<1$ volt, a $1 / C^{3}$ low is found. The junction built in potential derived from these measurements $\left(V_{b} \sim 0.6\right.$ volt $)$, is lower than the value found for a thermal diffused junction ( $\sim 0.9 \mathrm{~b}$ volt).

This behaviour can be analyzed in terms of a compensation effect of the P-type substrates doping level $\left(\sim 1 \times 10^{16} \mathrm{~cm}^{-3}\right)$, by the electrically active $N$-type defects created by the laser treatment.

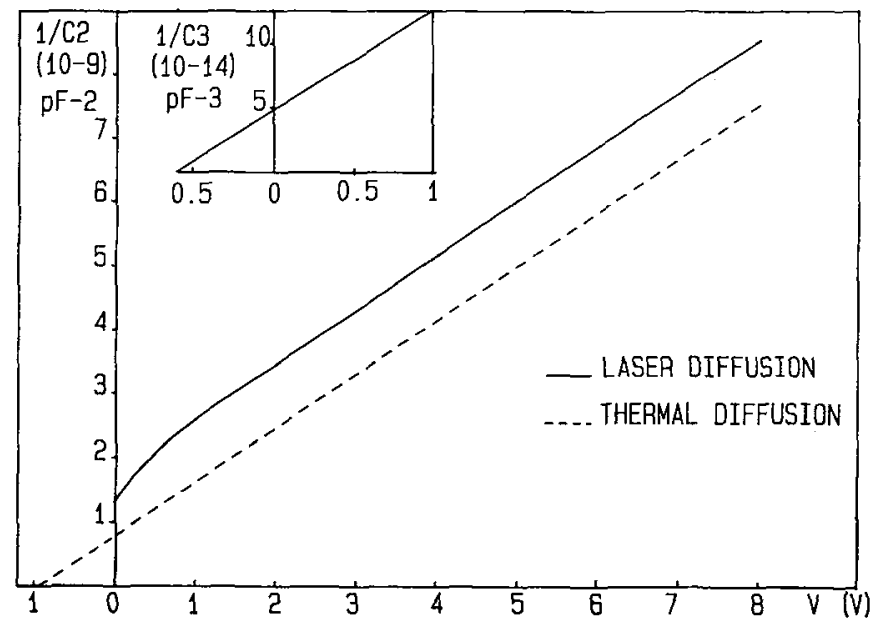

Fig. 4 - C - V characteristics for a thermal diffused junction (-.-) and laser processed junction (-). 


\section{SOLAR CELL PERFORMANCE}

We have reported on Fig. 5, the evolution of open-circuit voltage and short circuit current for three series of four cells $\left(1.3 \mathrm{~cm}^{2}\right.$ area) as a function of the incident laser energy density. The fill factors are ranging between 0.74 and 0.76 . The best results are measured for an energy density of $2 \mathrm{~J} / \mathrm{cm}^{2}$ and the highest open-circuit voltage $\left(V_{0 C}=585 \mathrm{mV}\right)$ are obtained without the use of any substrate heating. We must notice that these values found for the open circuit voltage, limited by the excessive recombination currents in the emitted region, are higher then those obtained, in a previous work 12 , by using a large single pulsed ruby laser $\left(V_{\text {oc }}=560 \mathrm{mV}\right.$ ).

This difference is mainly related to the increase of the junction depth $/ 8 /$, as confirmed by RBS experiments, by using the overlapping pulsed YAG laser $\left(X_{J} \sim 4000 \AA\right)$, compared to the single pulsed ruby laser $\left(X_{j} \sim 3000 A\right)$.

The photovoltaic characteristics of the two best laser processed solar cells (1.3 and $7.07 \mathrm{~cm}^{2}$ area, respectively) are reported on Table I.

A maximum conversion efficiency of $15.5 \%$, with an anti-reflective coating, is obtained and higher efficiencies (> 16\% AM1) are expected by the optimization of the different stages of the solar cell fabrication (surface passivation, back surface field, grid contacts ....)

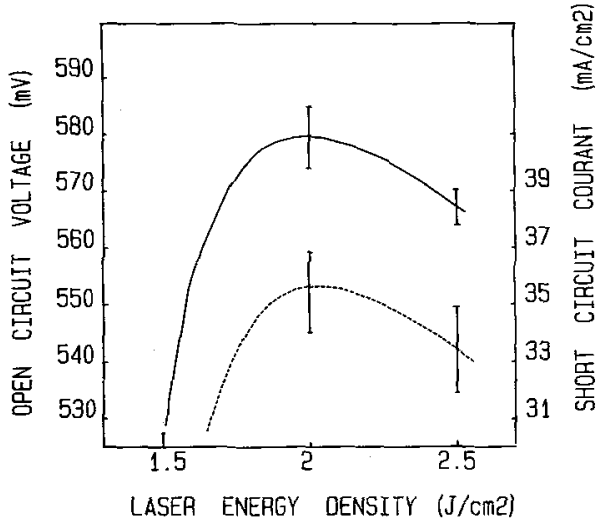

Fig. 5 - Evolution of $\mathrm{V}_{\mathrm{OC}}$ and $\mathrm{I}_{S C}$ as a function of the incident laser energy density.

\section{CONCLUSION}

We have demonstrated the feasability of an overlapping pulsed laser system to induce the diffusion of a dopant $f i l m$ deposited on silicon substrate. This leads to the fabrication of large area high efficiency silicon solar cells.

The achieved photovoltaic characteristics, $n \sim 15.5 \%$ under AM1 illumination conditions, are to our knowledge the best results, presently published by using the laser induced diffusion processing.

\section{REFERENCES}

1. NARAYAN J., YOUNG R.T., WOOD R.F. and CHRISTIE W.H.. App]. Phys. Lett. 33 (1978) 338.

2. FOGARASSY E., STUCK R., GROB J.J. and SIFFERT P.. J. App 1. Phys. 52 (2) (1981) 1076.

3. KODERA H.. Japan J. App 1. Phys. 2 (1963) 212.

4. TOULEMONDE $H$. and HEDDACHE R.. (üpublished) 
5. STUCK R., FOGARASSY E., GROB J.J. and SIFFERT P.. App T. Phys. 23 (1980) 15.

6. WILLIAMS J.S., BROWN W.L., CELLER G.K., LEAMY H.J., POATE J.M., ROZGONYI C.A. and SHENG T.T.. J. Appl. Phys. 52 (2) (1981) 1038.

7. KIMERLING L.C. and BENTON J.L.., "Laser and Electron Beam Processings of materials". Edited by C.W. VHITE and P.S. PEERCY, Academic Press (1980) p. 385.

8. SHIBIB Ayman M. and FOSSUM Jerry G.. J. Appl. Phys. 52 (2) (1981) 1072.

\begin{tabular}{|c|c|c|}
\hline 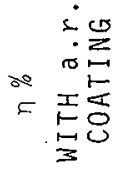 & $\sum_{n \rightarrow 1}^{L}$ & $\stackrel{\square}{\sim}$ \\
\hline L. & $\stackrel{n}{0}$ & $\hat{0}$ \\
\hline 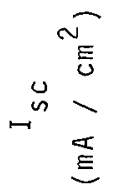 & $\stackrel{m}{m}$ & $\ddot{m}$ \\
\hline$\stackrel{0}{\circ}$ & $\frac{10}{10}$ & $\begin{array}{l}\text { N } \\
\text { in }\end{array}$ \\
\hline$\underset{\widetilde{U}}{\stackrel{\widetilde{N}}{\alpha}}$ & $\stackrel{m}{m}$ & ㅇ. \\
\hline 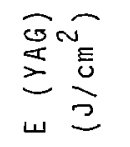 & $\sim$ & $\sim$ \\
\hline$\underset{⿱ 乛}{\stackrel{\Xi}{F}}$ & $\begin{array}{c}0< \\
0 \\
0 \\
\text { 용 }\end{array}$ & $\begin{array}{l}\text { a } \\
\text { in } \\
\text { in }\end{array}$ \\
\hline 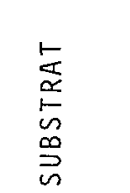 & $\begin{array}{l}\overrightarrow{=} \\
ت \\
ت \\
\bar{\Xi} \\
\bar{\sim}\end{array}$ & $\begin{array}{l}\overrightarrow{7} \\
=1 \\
= \\
\text { st }\end{array}$ \\
\hline
\end{tabular}

\begin{tabular}{l}
-1 \\
$w$ \\
$\infty$ \\
\hline
\end{tabular} 